\title{
PENGEMBANGAN PERANGKAT PEMBELAJARAN \\ BERBASIS PENDEKATAN ACCELERATED LEARNING PADA MATA PELAJARAN BAHASA INDONESIA
}

\author{
Elia Rosa \\ eliarosa68@gmail.com \\ SD Negeri 003 Tasik Juang, Airmolek, Indonesia
}

\begin{abstract}
Learning devices are tools or components used in the learning process needed to support the learning process. the purpose of this study is to develop learning tools based on the accelerated learning approach. The implementation of this research was carried out on the third grade students of SDN 003Tasik Juang. This research is a research development. Product trials are carried out in two stages, namely with trial 1 (limited test) and trial 2 (limited deployment). The results of the study showed that, learning tools developed using the accelerated learning approach were declared valid and feasible to be used by obtaining a percentage of $83.5 \%$ the category was very valid. Learning tools developed using the accelerated learning approach are declared practical based on the results of the observation sheet of the implementation of the learning process with an average value of 87.5 very good categories as well as from student questionnaire response data with an average value of 88.5 with very good categories. The learning tools developed are effective based on the acquisition of learning outcomes that are above the minimum completeness criteria with classical completeness of $84.9 \%$. Based on these results it can be concluded that the development of learning tools based on a valid, practical, and effective accelerated learning approach was developed in students of class III SDN 003 Tasik Juang.
\end{abstract}

Keywords: research development, learning tools, accelerated learning approach

\begin{abstract}
ABSTRAK
Perangkat pembelajaran merupakan sejumlah alat atau komponen yang digunakan di dalam proses pembelajaran yang diperlukan dalam mendukung proses pembelajaran. tujuan penelitian ini adalah untuk mengembangkan perangkat pembelajaran berbasis pendekatan accelerated learning. Pelaksanaan penelitian ini dilakukan pada siswa kelas III SD Negeri 003 Tasik Juang. Penelitian ini merupakan penelitian pengembangan. Uji coba produk dilakukan dengan dua tahap, yaitu dengan uji coba 1 (uji terbatas) dan uji coba 2 (penyebaran terbatas). Adapun hasil penelitian menunjukan bahwa, perangkat pembelajaran yang dikembangkan dengan menggunakan pendekatan accelerated learning dinyatakan valid dan layak untuk dapat digunakan dengan memperoleh persentase sebesar $83.5 \%$ kategori sangat valid. Perangkat pembelajaran yang dikembangkan dengan menggunakan pendekatan accelerated learning dinyatakan praktis berdasarkan hasil penilaian lembar observasi keterlaksanaan proses pembelajaran dengan nilai rata-rata sebesar 87.5 kategori sangat baik seta dari data angket respon siswa dengan nilai rata-rata 88.5 dengan kategori sangat baik. Perangkat pembelajaran yang dikembangkan dinyatakan efektif berdasarkan pemerolehan hasil belajar yang berada di atas KKM dengan ketuntasan secara klasikal $84.9 \%$. Berdasarkan hasil ini dapat disimpulkan bahwa pengembangan perangkat pembelajaran berbasis pendekatan accelerated learning valid, praktis, serta efektif dikembangkan pada siswa kelas III SD Negeri 003 Tasik Juang.
\end{abstract}

Kata Kunci: penelitian pengembangan, perangkat pembelajaran, pendekatan accelerated learning

\begin{tabular}{|c|c|c|}
\hline Submitted & Accepted & Published \\
\hline 13 Juli 2019 & 31 Oktober 2019 & 12 November 2019 \\
\hline
\end{tabular}

\begin{tabular}{|l|c|c|c|c|}
\hline Citation & $:$ & Rosa, E. (2019). Pengembangan Perangkat Pembelajaran Berbasis Pendekatan Accelerated Learning pada Mata Pelajaran \\
& & $\begin{array}{l}\text { Bahasa Indonesia. Jurnal PAJAR (Pendidikan dan Pengajaran), 3(6), 1232-1238. DOI : } \\
\text { http://dx.doi.org/10.33578/pjr.v3i6.7881. }\end{array}$ & \\
\hline
\end{tabular}

\section{PENDAHULUAN}

Perangkat pembelajaran adalah seperangkat alat atau perlengkapan dalam melaksanakan proses yang memungkinkan guru dan siswa melakukan kegiatan pembelajaran. Perangkat pembelajaran menjadi pegangan bagi guru dalam melaksanakan pembelajaran baik di

kelas, laboratorium atau di luar kelas (Zuda dkk. dalam Marzuki, 2018).

Perangkat pembelajaran memiliki berbagai komponen yang ada di dalamnya. Komponen-komponen itu tentunya memiliki pengertian, bentuk, dan format yang berbeda. Trianto (di dalam Yurnalis, 2018) menjelaskan, 
bahwa terdapat beberapa komponen perangkat pembelajaran, di antaranya berupa silabus, RPP, media, dan evaluasi pembelajaran. Oleh sebab itu setiap guru harus memiliki perangkat pembelajarannya masing-masing sesuai dengan kelas, kebutuahan, dan tingkat intelektual siswa.

Berdasarkan hasil observasi di kelas III SDN 003 Tasik Juang, terdapat kendala dalam proses pembelajaran yaitu guru di dalam mengajar masih menggunakan perangkat pembelajaran yang lama. Selain itu, guru masih menggunakan metode ceramah dalam menyampaikan pembelajaran. Guru belum menggunakan media pembelajaran yang sesuai dengan materi, sehingga siswa tidak tertarik mengkuti pelajaran. Pembelajaran masih berpusat pada guru sehingga kegiatan pembelajaran menjadi kurang efektif karena siswa menjadi tidak aktif karena hanya mendengar penjelasan dari guru. Dari permasalahan yang timbul di atas, menyebabkan hasil belajar siswa belum maksimal, hal ini dibuktikan oleh masih banyaknya siswa yang memperoleh nilai di bawah kriteria ketuntasan minimal (KKM) yang telah ditetapkan sekolah sebesar 70.

Permasalahan yang peneliti temui di atas, sejalan dengan permasalahan yang dikemukakan oleh Yurnalis (2018) yang menyatakan bahwa: 1) guru sering mengambil jalan pintas dalam pembelajaran seperti tidak membuat persiapan tertulis dalam mengajar dalam artinya tidak membuat perangkat pembelajaran seperti Silabus, RPP, Media, dan Evaluasi); 2) tidak jarang guru

\section{KAJIAN TEORETIS \\ Penelitian Pengembangan}

Penelitian pengembangan adalah penelitian yang menghasilkan produk tertentu dan menguji keefektifan produk tersebut (Sugiyono, 2009). Lebih lanjut pendapat Putra (2012) menjelaskan, penelitian pengembangan merupakan metode penelitian yang secara sengaja, sistematis bertujuan untuk mencari, menemukan, merumuskan, memperbaiki, mengembangkan, menghasilkan, menguji keefektifan produk yang lebih unggul, baru, efektif, efisien, produktif, dan bermakna. mengabaikan perbedaan siswa; 3) guru merasa paling pandai; 4) sering sekali guru bertindak tidak adil (diskriminatif). Lebih lanjut, Marzuki (2018) menemukan permasalahan pada beberapa guru seperti: 1) kurangnya kemampuan guru dalam membuat perangkat pembelajaran; 2) perangkat pembelajaran hanya dijadikan sebagai pelengkap dan bukan untuk kebutuhan mengajar; 3) sedangkan sebagian guru lagi tidak memiliki atau tidak membuat perangkat pembelajaran.

Keadaan tersebut di atas, merupakan sumber inspirasi bagi penulis untuk melakukan suatu penelitian ilmiah berkaitan dengan kemampuan guru dalam mengembangkan perangkat pembelajaran berbasis pendekatan accelerated learning. Pendekatan accelerated learning merupakan pendekatan yang dapat menggugah sepenuhnya kemampuan belajar siswa, membuat belajar siswa menjadi menyenangkan dan memuaskan bagi siswa, serta memberikan sumbangan sepenuhnya pada kebahagian, kecerdasan, kompetensi, dan keberhasilan siswa dalam pembelajaran (Meier, 2002).

Tujuan accelerated learning adalah mendorong siswa untuk memaksimalkan proses belajar dengan cara menghargai kebutuhan dari beragam individu yang berbeda dan salah satu alasan utama mengapa accelerated learning membantu manusia untuk belajar lebih cepat dan efisien adalah karena accelerated learning menghargai perbedaan preferensi proses pembelajaran individu (Russel, 2011).

Berdasarkan pendapat di atas, dapat disimpulkan bahwa penelitian pengembangan merupakan sebuah penelitian yang digunakan untuk mengembangkan sebuah produk melalui tahapan tertentu, hingga nantinya dihasilkan sebuah produk yang teruji tingkat kevalidan, kepraktisan, dan kefektifannya terhadap kebutuhan.

\section{Pengertian Accelerated Learning}

Russel (2011:5), "Accelerated learning adalah mengubah kebiasaan dengan meningkatkan kecepatan". Sementara itu, menurut Meier (2002:26), "Accelerated learning pendekatan yang 
paling maju yang digunakan pada masa sekarang, dan mempunyai banyak mamfaat. Accelerated learning didasarkan pada penelitian mutakhir mengenai otak dan belajar. Siswa diajak terlibat sepenuhnya. Accelerated learning cocok dengan semua gaya belajar dan memberi energi serta membuat proses belajar menjadi manusiawi kembali. Accelerated learning membuat belajar menyenangkan dan benar-benar sangat mementingkan hasil".

Berdasarkan pendapat di atas dapat disimpulkan bahwa pendekatan accelerated learning merupakan suatu pendekatan yang dapat mengatasi masalah dalam proses pembelajaran, yang memungkinkan peserta didik untuk dapat menciptakan aktivitas belajar menjadi menyenangkan serta dapat meningkatkan minat peserta didik terhadap pembelajaran. Accelerated learning dapat mengubah kebiasaan peserta didik dalam proses pembelajaran ke arah yang lebih baik dari sebelumnya dengan meningkatkan kecepatan dalam pembelajaran.

\section{METODE PENELITIAN}

Penelitian ini merupakan penelitian pengembangan perangat pembelajaran yang dilaksanakan di SD Negerri 003 Tasik Juang. Subjek uji coba dalam penelitian pengembangan ini adalah siswa kelas III SD Negeri 003 Tasik Juang. Subjek uji coba 1 (uji Terbatas) adalah 15 siswa yang dipilih secara acak. Subjek uji coba 2 (Penyebaran Terbatas) adalah 15 siswa. total semua sampel dalam penelitian ini adalah berjumlah 30 orang siswa yang memiliki kemampuan yang berbeda-beda. Uji coba produk dilakukan dengan dua tahap, yaitu dengan uji coba 1 (uji terbatas) dan uji coba 2 (penyebaran terbatas).

Instrumen untuk mengumpulkan data yang digunakan dalam penelitian ini adalah

\section{HASIL DAN PEMBAHASAN}

Tujuan dilaksanakan penelitian pengembangan ini adalah untuk menghasilkan sebuah perangkat pembelajaran dengan mengimplementasikan pendekatan accelerated learning bagi kelas III SD 003 Tasik Juang yang

\section{Perangkat Pembelajaran}

Perangkat pembelajaran adalah komponen perangkat yang digunakan untuk mengelola proses pembelajaran sehingga dapat mencapai kompetensi yang ingin dicapai secara maksimal (Trianto, 2011). Lebih lanjut, Suhadi (2007) mengemukakan bahwa perangkat pembelajaran adalah sejumlah bahan, alat, media, petunjuk dan pedoman yang akan digunakan dalam proses pembelajaran. Perangkat yang dipergunakan dalam proses pembelajaran disebut dengan perangkat pembelajaran.

Berdasarkan pendapat para ahli di atas maka dapat disimpulkan bahwa perangkat pembelajaran merupakan sejumlah alat atau komponen yang digunakan di dalam proses pembelajaran yang diperlukan untuk melakukan persiapan pembelajaran agar proses pembelajaran dapat tercapai dengan baik.

lembar validasi, lembar observasi, angket, tes hasil belajar. Analisis kelayakan perangkat pembelajaran dilakukan melalui lembar validasi. Hasil validasi kemudian diubah menjadi persentase dan diklasifikasikan ke dalam beberapa kategori interpretasi. Analisis kepraktisan perangkat pembelajaran dilakukan melalui lembar observasi pada proses pembelajaran, aktivitas siswa, dan angket respon siswa. Hasil lembar observasi dan angket kemudian diubah menjadi persentase yang diklasifikasikan ke dalam beberapa kategori interpretasi. Selanjutnya, analisis keefektifan perangkat pembelajaran dapat dilihat melalui angket motivasi belajar dan tes hasil belajar siswa.

valid, praktis, dan efektif. Perangkat pembelajaran tersebut meliputi silabus pembelajaran, rencana pelaksanaan pembelajaran (RPP), media pembelajaran, dan evaluasi pembelajaran. 


\section{Validitas Peangkat Pembelajaran}

Hasil dari kevalidan perangkat pembelajaran dengan menggunakan pendekatan accelerated learning diperoleh dari lembar validasi perangkat pembelajaran yang diisi oleh validator. Pada tahap validasi dilakukan penilaian terhadap perangkat pembelajaran yang diberikan oleh validator. Selain itu dilakukan revisi hasil validasi dengan cara menelaah masukan diberikan oleh validator dan melakukan perbaikan perangkat pembelajaran berdasarkan masukan oleh validator. Adapun validator dalam penelitian ini adalah kepala sekolah peneliti sendiri dan pengawas sekolah. Hasil validasi perangkat pebelajaran yang meliputi Silabus, RPP, Media, dan evaluasi pembelajaran disajikan pada tabel 1 di bawah ini:

Tabel 1. Hasil Validasi Perangkat Pembelajaran

\begin{tabular}{lcl}
\hline \multicolumn{1}{c}{ Lembar Validasi } & Persentase & Kategori \\
\hline Silabus & 83.3 & Sangat Valid \\
\hline $\begin{array}{l}\text { Rencana Pelaksanaan } \\
\text { Pembelajaran (RPP) }\end{array}$ & 88.8 & Sangat Valid \\
\hline Media Pembelajaran & 75 & Valid \\
\hline Evaluasi Pembelajaran & 87 & Sangat Valid \\
\hline Jumlah & 83.5 & Sangat Valid \\
\hline
\end{tabular}

Berdasarkan data pada tabel 1 di atas setelah angka dianalisis, terlihat bahwa nilai lembar validasi rata-rata untuk setiap komponen perangkat pembelajaran berkisar antara 75 s.d 88.8 yang berada pada kategori valid dan sangat valid. Validari silabus memperoleh nilai sebesar 83.3 dengan kategori sangat valid. Validasi rencana pelaksanaan pembelajaran (RPP) memperoleh nilai sebesar 88.8 dengan kategori sangat valid. Media pembelajaran memperoleh nilai sebesar 75 dengan kategori valid, sedangkan evaluasi pembelajaran memperoleh nilai sebesar 87 dengan kategori sangat valid. Untuk nilai ratarata keseluruhan validasi perangkat pembelajaran memperoleh penilaian sebesar 83.5 dengan kategori sangat valid. Dari hasil validasi ini menunjukan bahwa perangkat telah disusun sesuai dengan kaidah bahasa Indonesia yang baik dan benar, sistematis, substansi isi yang sesuai, serta bahan ajar yang dirancang telah mempunyai tampilan yang baik dan menarik. Dengan hasil ini dapat disimpulkan bahwa secara keseluruhan perangkat pembelajaran dengan mengimplementasikan pendekatan accelerated learning sudah valid menurut parah ahli.

\section{Praktikalitas Perangkat Pembelajaran}

Hasil kepraktisan perangkat pembelajaran dengan menggunakan pendekatan accelerated learning bagi kelas III SD Negeri 003 Tasik Juang dapat diperoleh dari lembar observasi keterlaksanaan pembelajaran dan angket respon yang diisi oleh para siswa. Lembar pengamatan keterlaksanaan proses pembelajaran digunkan untuk mengetahui kesesuaian antara proses pembelajaran dengan RPP yang menggunakan pendekatan accelerated learning. Lembar angket respon siswa digunakan untuk mengetahui respon awal dan ketertarikan siswa terhadap perangkat pembelajaran. Hasil lembar observasi keterlaksanaan pembelajaran dapat dilihat pada tabel 2 di bawah ini: 
Tabel 2. Hasil Keterlaksanaan Pembelajaran Menggunakan Pendekatan Accelerated Learning

\begin{tabular}{ccc}
\hline Pertemuan & Persentase & Kategori \\
\hline 1 & 84.2 & Sangat Baik \\
\hline 2 & 86.6 & Sangat Baik \\
\hline 3 & 88.1 & Sangat Baik \\
\hline 4 & 89.3 & Sangat Baik \\
\hline Rata-Rata & 87.5 & Sangat Baik \\
\hline
\end{tabular}

Berdasarkan data pada tabel 2 di atas setelah angka dianalisis, terlihat bahwa nilai kepraktisan untuk setiap pertemuan berkisar antara 84.2 s/d 89.3 yang berada pada kategori sangat baik. Pertemuan pertama memperoleh nilai sebesar 84.2 dengan kategori sangat baik. Pertemuan kedua memperoleh nilai sebesar 86.6 dengan kategori sangat baik. Pertemuan ketiga memperoleh nilai sebesar 88.1 dengan kategori sangat baik, sedangkan pertemuan keempat memperoleh nilai sebesar 899.3 dengan kategori sangat baik. Untuk nilai rata-rata keseluruhan pertemuan sebesar 87.5 dengan kategori sangat baik. Berdasarkan hasil penilaian di atas, secara umum keterlaksanaan pembelajaran dapat berjalan sesuai rencana dan berjalan dengan baik. Angket respon siswa terhadap perangkat pembelajaran diberikan kepada siswa setelah pembelajaran selesai dilaksanakan. Angket respon siswa diberikan pada saat uji coba terbatas dan penyebaran terbatas. Tahap uji coba pertama yaitu uji coba terbatas yang terdiri dari 15 responden dan penyebaran terbatas terdiri dari 15 responden. Hasil angket respon siswa terhadap perangkat pembelajaran pada uji coba terbatas dan penyebaran terbatas dapat dilihat pada tabel 3 di bawah ini:

Tabel 4. Penilaian Respon Siswa

\begin{tabular}{ccc}
\hline Pelaksanaan & Pesentase Respon & Kategori \\
\hline Uji Coba Terbatas & 87 & Sangat Baik \\
\hline Penyebaran Terbatas & 90 & Sangat Baik \\
\hline Rata-Rata & 88.5 & Sangat Baik \\
\hline
\end{tabular}

Berdasarkan tabel 4 di atas, diketahui bahwa persentase yang diperoleh untuk angket respon siswa dalam pelaksanaan uji coba terbatas adalah sebesar 87 dengan kategori sangat baik. Persentase untuk angket respon siswa dalam penyebaran terbatas adalah sebesar 90 dengan kategori sangat baik. Hal ini menunjukkan bahwa siswa menunjukan ketertarikannya terhadap perangkat pembelajaran yang telah dikembangkan berbasis pendekatan accelerated learning.

\section{Efektivitas Perangkat Pembelajaran}

Setelah dilakukan praktikalitas, dilanjutkan menguji efektiviatas bahan ajar. Efektivitas bahan ajar dapat dilihat dari hasil penilaian belajar siswa. Penilaian hasil merupakan penilaian yang berkaitan dengan pemahaman siswa terkait materi yang diperoleh dari hasil tes di akhir pembelajaran. adapun hasil penilaian dapat dilihat pada tabel 5 di bawah ini:

Tabel 5. Persentase Ketuntasan Penilaian Hasil Belajar Siswa

\begin{tabular}{|c|c|c|c|c|c|c|}
\hline \multirow{2}{*}{$\begin{array}{c}\text { Jumlah } \\
\text { Siswa }\end{array}$} & \multicolumn{4}{|c|}{ Rata-rata Nilai \% } & \multirow{2}{*}{ KKM } & \multirow{2}{*}{$\begin{array}{c}\text { Ketuntasan } \\
(\%)\end{array}$} \\
\hline & PB1 & PB2 & PB3 & PB4 & & \\
\hline 30 & 76.6 & 83.3 & 86.6 & 93.3 & 70 & $84.9 \%$ \\
\hline
\end{tabular}




\begin{abstract}
Dari tabel 5 di atas setelah angka dianalisis, diperoleh gambaran bahwa pembelajaran dengan perangkat pembelajaran berbasis berbasi pendekatan accelerated learning dapat membantu siswa dalam memahami pelajaran dengan baik. Hal ini dapat dibuktikan dari perolehan penilaian hasil evaluasi pembelajaran. Di mana pada pembelajaran 1 diperoleh nilai rata-rata sebesar 76.6 atau 23 siswa yang mendapat nilai diatas KKM sedangkan 7 siswa di bawah KKM. Pada pembelajaran 2 diperoleh nilai rata-rata sebesar 83.3 atau 25 siswa yang mendapat nilai diatas KKM sedangkan 5 siswa di bawah KKM. Untuk pembelajaran 3 dipeoleh nilai rata-rata sebesar 86.6 atau 26 siswa yang mendapat nilai diatas KKM, sedangkan 4 siswa di bawah KKM. Sedangkan pada pembelajaran 4 diperoleh nilai rata-rata sebesar 93.3 atau 28 siswa yang mendapat nilai diatas KKM sedangkan 2 siswa di bawah KKM.
\end{abstract}

Melihat paparan di atas, perangkat pembelajaran berbasis pendekatan accelerated learning yang telah dikembangkan sudah efektif digunakan di kelas III SD Negeri 003 Tasik

\section{SIMPULAN DAN REKOMENDASI}

Berdasakan uraian hasil penelitian di atas, peneliti menyimpulkan bahwa:

1. Perangkat pembelajaran yang dikembangkan dengan menggunakan pendekatan accelerated learning dinyatakan valid dan layak untuk dapat digunakan dalam proses pembelajaran berdasarkan penilaian validator.

2. Perangkat pembelajaran yang dikembangkan dengan menggunakan pendekatan accelerated learning dinyatakan praktis berdasarkan hasil penilaian lembar observasi keterlaksanaan proses pembelajaran seta dari data angket respon siswa;

3. Perangkat pembelajaran yang dikembangkan dengan menggunakan pendekatan accelerated

\section{DAFTAR PUSTAKA}

Afendi, N., Mudjiran., Arif, D., \& Misliati. (2019). Development of Teaching Materials Reading Comprehension Based On
Juang. Keefektivan dapat dilihat dari pemerolehan hasil belajar yang berada di atas KKM dengan ketuntasan secara klasikal $84.9 \%$. Sementara itu, batas minimal suatu perangkat pembelajaran dikatakan efektif apabila diperoleh ketuntasan hasil belajar secara klasikal $\geq 75$. Dengan demikian, dapat disimpulkan bahwa pembelajaran yang telah dilaksanakan dengan menggunakan perangkat berbasis pendekatan accelerated learning yang dikembangkan telah berhasil diterapkan.

Hasil penelitian ini sejalan dengan penelitian Afendi (2019) yang menyatakan penelitian pengembangan sangat efektif dilaksanakan dalam rangka memecahkan permasalahan pembelajaran yang dihadapi siswa maupun guru di sekolah dasar. Baik dalam segi proses maupun hasil pembelajaran. Penelitian pengembangan itu sendiri memiliki kelebihan seperti guru dapat menyesuaikan bahan ajar beserta perangkat pembelajaran yang sesuai dengan kebutuhan dan karakteristik siswa, sebab siswa SD suka bahan ajar yang penuh gradasi warna dan gambar-gambar yang menarik dan bisa mendukung pembelajaan.

learning dinyatakan efektif berdasarkan peningkatan hasil evaluasi belajar siswa setiap pembelajarannya.

Berdasarkan kesimpulan hasil penelitian di atas, maka peneliti memberikan rekomendasi agar hasil penelitian pengembangan ini dapat dijadikan bahan masukan serta menjadi referensi oleh guru lain, baik di sekolah tempat peneliti maupun untuk guru-guru di sekolah lain. Diharapkan guru dan peneliti sendiri senantiasa dapat menerapkan pembelajaran dengan menggunakan pendekatan accelerated learning agar siswa lebih aktif dalam mengikuti pembelajaran.

Cooperative Integrated Reading and Composition (CIRC) Strategy As Character Education In Class VI Elementary School. 
Jurnal PAJAR (Pendidikan dan Pengajaran), 3(5), 983-994. DOI: http://dx.doi.org/10.33578/pjr.v3i5.7810.

Marzuki. (2018. Penerapan Metode Pemberian Tugas untuk Meningkatkan Kemampuan Guru dalam Membuat Perangkat Pembelajaran SD Negeri 001 Empat Balai Kabupaten Kampar. Jurnal PAJAR (Pendidikan dan Pengajaran), 1(1), 82-93.

Meier, D. (2003). The Accelerated Learning Handbook: Panduan Kreatif dan Efektif Merancang Program Pendidikan dan Pelatihan. Bandung: Kaifa.

Putra, N. (2012). Metode Penelitian Kualitatif Pendidikan. Jakarta: Raja Grafindo Persada.

Russel, L. (2011). The Accelerated Learning Fieldbook. (M Irfan Zakkie. Terjemahan).
San Francisco: Jossey-Bass. Buku asli diterbitkan tahun 1999.

Sugiyono. (2009). Metodologi Penelitian Pendidikan Kuantitatif, Kualitatif, dan $R \& D$. Bandung: Alfabeta.

Suhadi. (2007). Petunjuk Perangkat Pembelajaran. Surakarta: Universitas Muhammadiyah.

Trianto. (2007). Model Pengembangan Terpadu dalam Teori dan Praktek. Jakarta: Prestasi Pustaka.

Yurnalis. (2018). Upaya Meningkatkan Kemampuan Guru dalam Menyusun Perangkat Pembelajaran melalui Supervisi Klinis di Sekolah Binaan Kecamatan Cerenti. Jurnal PAJAR (Pendidikan dan Pengajaran), 2(4), 505-515. 